\title{
Overview: Livelihood Re-Establishment After Resettlement due to Dam Construction
}

\author{
Ryo Fujikura (Corresponding author) \\ Faculty of Sustainability Studies, Hosei University \\ Fujimi 2-17-1, Chiyodaku, Tokyo, 102-8160 Japan \\ E-mail: Fujikura@hosei.ac.jp
}

Mikiyasu Nakayama

Graduate School of Frontier Sciences, The University of Tokyo

Tel: 81-4-7136-4869Ｅ-mail: nakayama@k.u-tokyo.ac.jp

Received: February 10, 2019 Accepted: February 15, 2019 Published: February 28, 2019

doi:10.5296/jad.v5i1.14420 URL: https://doi.org/10.5296/jad.v5i1.14420

\begin{abstract}
This special issue features case studies carried out in Indonesia, Japan, and Sri Lanka, in which at least one of the following issues was observed and studied: (a) long-term (a few to several decades) implications of resettlement on livelihood re-establishment, (b) resettlement from rural areas with agriculture- or forestry-based economies to cities, and (c) gender issues associated with resettlement and livelihood re-establishment. These case studies were conducted for the purpose of examining how the planning and operation of the resettlement process affected residents reconstructing their livelihood. We conclude that there is still room for improvement in how compensation for resettlers and their livelihood re-establishment should be addressed by dam developers. We found that very limited attention has been paid to the gender issue in designing and implementing compensation packages for resettlers. And we also note that resettlers are not the only populations that need to be cared for. Dam construction also has an impact on non-resettlers in the project command area whose assets are not submerged. Their livelihood tends to be worse off after completion of a dam and reservoir. Infrastructure development in the project command area, particularly improvement of traffic systems, should be undertaken both for non-resettlers and resettlers who need or decide to live in the same area as before the construction.
\end{abstract}

Keywords: compensation, dam, Indonesia, Japan, livelihood, resettlement, Sri Lanka 


\section{Introduction}

Demand for energy and water is increasing in developing countries. The Paris Agreement (UNFCCC, 2015) was adopted in 2015 as a global agreement within the United Nations Framework Convention on Climate Change (UNFCCC) for reducing greenhouse gas emissions. This agreement obliged both developed and developing countries to set mitigation targets. Hydroelectric power is a feasible option for meeting the rapidly increasing demand for electricity while curbing carbon dioxide emissions. According to the New Policies Scenario (Note 1) modeled by the International Energy Agency (IEA), hydropower generation capacity in the Asia-Pacific region (excluding China) will increase from 1,657 TWh to 2,634 TWh during 2017-2040 (IEA, 2018a). In order to achieve the internationally agreed-upon sustainable development goals related to energy, as modeled in IEA's Sustainable Development Scenario (SDS) (Note 2), the capacity will have to further expand to 3,115 TWh (IEA, 2018a).

Demand for irrigation water is also increasing in developing countries to meet the need for animal foods due to population growth and economic development. In the Asian monsoon zone, where rainy and dry seasons exist, agricultural production during the dry season is marginal without irrigation. The land area equipped for irrigation in Asia increased from 106 million to 236 million ha between 1961 and 2015 (FAO, 2019). Chellaney (2011) predicts that 2,500 to $6,000 \mathrm{~km}^{3}$ of water will be additionally required if (a) agricultural productivity does not change significantly, (b) the world population increases to 9 billion, and (c) average daily food consumption reaches 2,500 calories per capita. In order to meet such demands for water, 25 to 60 large dams comparable to the Aswan High Dam of Egypt will have to be developed.

Large dams are a feasible option for responding quickly to increasing demand for electricity and water. However, they often force a large number of people to resettle because of the construction. In many dam construction projects, livelihood reconstruction for resettlers resulted in failure due to lack of or poor resettlement plans. The World Commission on Dams (WCD) conducted comprehensive comparative studies on 125 existing large dams and intensive studies on eight dams. It published its report in 2000 with recommendations for dam development (World Commission on Dams, 2000). However, the recommendations were not adopted by the World Bank and were rejected by some Asian countries such as India and Nepal. The WCD, therefore, failed to establish widely accepted norms for dam development.

The Asian Development Bank (ADB) announced its Safeguard Policy Statement in 2009. This includes a safeguard requirement on involuntary resettlement, including criteria for compensation and land acquisition.

At least 480,000 people have been resettled as a result of 151 projects funded by the World Bank since 1990, and the number of projects involving resettlement is increasing (World Bank, 2012). In 2015, Jim Yong Kim, then-President of the World Bank admitted, "We found several major problems. One is that we haven't done a good enough job in overseeing projects involving resettlement; two, we haven't implemented those plans well enough; and three, we haven't put in place strong tracking systems to make sure that our policies were 
being followed. We must and will do better" (World Bank, 2015). After he initiated an action program for improvement, the World Bank adopted the Environmental and Social Framework (ESF) and has applied it to all new World Bank projects since October 2018. The ESF clearly presents issues to consider in the case of involuntary resettlement.

A number of case studies on dam relocation have been conducted since the WCD reports (for example, Cernea, 2003; Scudder, 2005; Padovani, 2016). In cooperation with researchers from each of the six countries included, the authors have also evaluated resettlement due to construction of 17 large dams in six Asian countries (Fujikura \& Nakayama, 2015). In most of the cases we investigated, the resettlement had occurred at least 20 years prior to the study. As a result, we learned the following lessons.

- What is important is not to reduce the number of risk items, but to reduce the overall risk.

- Land-for-land compensation should be a major option for resettlers, and resettlement packages not based on land-for-land schemes should also be prepared and shown to resettlers as alternative options.

- Because resettlers' intentions and choices are diverse, they must be involved in resettlement planning at the earliest stage possible.

- There are some occupations in urban areas which do not require any specific vocational training or speaking ability in the standard language of the country or region.

- Education of second generation resettlers is always a crucial factor for satisfying the first generation resettlers.

- Monitoring should be continued for as long as possible.

- A fund, established with a small part of the benefit obtained from the dam, should be considered for future countermeasures against unexpected events and/or maintenance of infrastructure such as roads.

- Mitigating resettlers' attachment to the submerged land is necessary but difficult.

- Opportunity and training to secure secondary income should be provided.

- When it seems to be difficult for first generation resettlers to entirely rehabilitate their livelihood, expectations from second generation resettlers should be explored.

The research team led by the authors, composed of researchers from Indonesia, Japan, and Sri Lanka since 2016, worked on the issue of "Policy and Practice on Livelihood Re-Establishment after Resettlement due to Dam Construction."

Five case studies have been carried out within the framework of this study. For all these cases, a survey was conducted among those who succeeded or failed in re-establishing their livelihood by (a) changing their occupations from farming to non-farming jobs (e.g., tourism, factory work, engineering, civil service, etc.), (b) maintaining their involvement in agriculture and forestry, and (c) securing a second income from side work (e.g., aquaculture), while 
maintaining their original farming jobs.

This special issue features case studies in which at least one of the following issues was observed and studied: (a) long-term (a few to several decades) implications of resettlement for livelihood re-establishment, (b) resettlement from rural areas with an agriculture- or forestry-based economy to cities, and (c) gender issues associated with resettlement and livelihood re-establishment.

These case studies were conducted to examine how the planning and operation of the resettlement process affected residents reconstructing their livelihood.

\section{Overview of Case Studies}

\subsection{Saguling Dam, Indonesia}

The Saguling Dam was built in West Bandung Regency, West Java Province, Indonesia, with the support of the World Bank and the Japanese government. Construction was completed in 1987. This project affected 10,664 families both directly and indirectly. There were 3,038 families forced to move because their land was submerged, and another 7,626 families had land and sources of income in the inundated area (PLN, 1989). It was expected that 2,000 households would participate in the transmigration program and relocate outside Java Island. However, only 74 households actually participated in the transmigration program and 2,416 households, equivalent to $78.4 \%$ of the submerged households, were relocated within the same village (Nakayama, 1998). As a result, it became impossible to provide enough farm land to the resettlers. The total paddy field area sharply decreased from $2,845,900 \mathrm{~m}^{2}$ to $137,900 \mathrm{~m}^{2}$. The World Bank proposed that resettlers conduct fish farming with floating net cages on the surface of the lake. However, the resettlers did not receive sufficient compensation to invest in fish farming. Moreover, outsiders started fish farming using many fish cages. As a result of excessive farming, the quality of the water deteriorated and fish production was greatly reduced (Sunardi et al., 2013).

Sunardi et al. (2019) investigated the lives of the resettlers using questionnaires and interviews in 2016 and 2018. The survey reported that 51 households relocated to the reservoir areas and 10 households relocated to peri-urban areas. Among the total 61 households surveyed, 48 were comprised of first generation household heads at the time of resettlement, whereas 13 were second generation household heads.

Annual household income decreased from USD 10,956 to USD 7,648 (based on the USD exchange rate of the time). Before resettlement, none of them was unemployed. After resettlement, 10 first generation individuals became jobless and the number of farmers was reduced to three, indicating worsening employment opportunities for farmers due to the decrease in farmland area. Among the second generation, 42 people worked as construction laborers and 81 were housewives. Employment among the second generation is more diverse than that of the first. There were also differences in levels of educational attainment. Among the 110 first generation residents, 26 did not graduate from elementary school, and 79 graduated only from elementary school. All of the 261 second generation residents have at least some elementary school education, and 138 people are elementary school graduates. 
The number of junior high school, high school, and university graduates are 45, 54, and 21 people, respectively. This indicates a certain improvement in education. Many residents used their compensation for investments. There are 61 people who responded about the use of compensation money, including 35 who invested in houses and land and seven who invested in education. Out of 51 respondents, 27 were unsatisfied with their relocation. However, the majority have established good relationships with the host community after resettlement, and no social friction was reported. This was partly because, luckily, there was no cultural difference between the resettlers and host communities.

\subsection{Jatigede Dam, Indonesia}

The Jatigede Dam was built in Sumedang Regency, West Java Province, Indonesia. It had been planned since the 1960s, but the World Bank decided to cancel the funding in 1982, given that the relocation plan was inadequate. However, the Indonesian government started land acquisition in that same year. About 10,000 households were to be submerged. The government expected that many households would participate in the transmigration program to relocate outside of Java Island. Although 911 households actually participated in the transmigration program, 121 of these households later returned to their original land. In 1995, the government offered relocation to two adjacent Regencies, and 496 households accepted. However, 406 of these households also returned to their original land (Suwartapradja et al., 2019).

Cash compensation of 6,000 rupiah (USD 5.90) per $14 \mathrm{~m}^{2}$ of submerged land was provided as compensation between 1984 and 1986. However, as the government was unable to start dam construction due to the lack of funds, the resettlers believed that dam construction was cancelled. Many households who had already moved returned to the project area and resumed farming. They have spent the compensation money on living expenses.

In 2007, the Indonesian government signed a contract for a loan of USD 239.57 million from the Chinese government, and Sinohydro, a Chinese construction company, started the dam construction. Submergence started in 2015, and resettlers were forcibly displaced. In the same year, the Indonesian government paid 122.5 million rupias (about USD 9,000) in average to 4,154 households that had already been relocated in the 1980s, and 29 million rupiahs (about USD 2,200) in average were given to 6,410 households that were relocated in 1993.

According to a survey conducted in 2016 among 3,886 households that resettled to four districts near the dam, almost all of them had been forcibly displaced in 2015. Of these, the number of households in which head of the family was unemployed increased to 3,634 from 3,058 before resettlement. In 2016, the monthly income of almost all the households was less than one million rupiah, which is lower than the international poverty line of USD 1.09 per day. It can thus be concluded that livelihood re-establishment has been unsuccessful up to the present. Of the 1,084 households who answered the questionnaire, 378 are interested to engage in fishing. Fish cage farming at the reservoir seems a promising way to improve economic conditions, but the West Java Province government plans to ban fish farming in reservoirs to avoid water pollution. 


\subsection{Shichikashuku Dam, Japan}

The majority of evaluations of, and research studies on, resettlement caused by dam development have focused on resettlers who moved away from submerged areas. However, detached areas upstream from reservoirs also suffer significantly from transport difficulties and declining populations. Less attention has been paid to the reconstruction of the detached areas, as compared with providing resettlers with compensation. The Japanese government adopted the Act on Special Measures for Reservoir Areas Development (ASMRAD) in 1973 to promote economic development of the areas around reservoirs through investing in development projects. Nakayama and Fujikura (2019) interviewed residents in a detached area near the Shichikashuku Dam in Japan about their personal experiences and the regional situation. A comparison was also made with the detached area created by Sameura Dam in Japan, which was planned before ASMRAD took in effect.

The Shichikashuku Dam was built in Miyagi Prefecture. Dam construction was planned in 1971 and detailed design started in 1973. The construction was completed in 1989, and 640 people from 158 households were resettled. ASMRAD was applied to the dam project and 53.5 billion Japanese yen, equivalent to $20 \%$ of the total cost of the project, was invested.

A municipal officer living in the detached area of the Shichikashuku Dam responded that he used to oppose the dam project officially, but he personally thought that it was a good opportunity. This was because (a) he had not been obliged to change his livelihood, for he was able to hold onto his position in the municipal government even after resettlement, (b) he had farmed as side work, but farming had brought only a small additional income, (c) he thus found no risk in livelihood re-establishment after relocation, and (d) compensation had implied that he would have received a great amount of money. The road to Shiroishi City, 25 $\mathrm{km}$ away and downstream from Shichikashuku Town, was improved under ASMRAD. For the children, this made possible the commute to a high school in the city. In addition, a large number of tourists now come from neighboring areas, contributing to the local economy (Nakayama \& Fujikura, 2019).

In contrast, ASMRAD was not applied to the Sameura Dam built in Kochi Prefecture in 1975. In this project, the central part of Okawa Village was submerged and a road was re-developed with many curves. It thus became difficult to move between the upstream and downstream areas of the basin. The population of Okawa, which had once exceeded 4,000, decreased to 396 by 2015, making it the smallest village in Japan except for the island villages.

\subsection{Tokuyama Dam, Japan}

Yamazawa and Moriya (2019) analyzed the gender issues associated with the resettlement due to the Tokuyama Dam construction in Japan in 2008. The Tokuyama Dam was built in Gifu Prefecture and 466 households began to resettle in 1984. Negotiations were conducted between stakeholders and the Japan Water Agency, the construction executing agency. Although women seldom attended local meetings in this area, they regularly participated in the negotiation because a daily allowance was provided for the participation. However, women were discouraged from actively speaking at local meetings at that time, and, thus, 
women seldom expressed their opinions.

Among the resettlers was a group called "dam brides" who are quite distinctive in the analysis of gender issues. These women had lived and worked in urban areas, and married with men from the area, which were to be submerged. The characteristics of this group of women are as follows.

- They firmly agreed to be resettled and they wished to stay in the project command area only for a short term.

- They were not satisfied with the infrastructure in the resettled areas, which was inferior to that in their hometown.

- They found new occupations without difficulty after resettlement.

- They experienced difficulties in establishing good relationships with their mothers-in-law.

- They generally established good relationships with people in the host community.

By comparing the attitudes and activities of Tokuyama local women and "dam brides", we discovered that the opinion of women was not reflected in formulating the relocation plan.

\subsection{Cases in Sri Lanka}

The case studies in Sri Lanka touch upon the gender issue, particularly in understanding how it should be addressed in compensation packages for resettlers in future dam development projects (Manatunge, Yamazawa, \& Samanpriya, 2019).

The construction of the Kotmale Dam was assumed to impose difficulties upon women for the following reasons: (a) women lost clusters of houses consisting of several nuclear families, which support and share the burden of their tasks such as house work, (b) people lost the traditional system of reciprocal exchange labor and they could not help each other due to caste differences and different places of origin, (c) a marriage style in which the husband lives in the wife's house was abandoned and women lost support from their family, (d) the lack of common lands led to women losing their access to such land for income generation, (e) women could not attend training programs for resettlement and social activities because of domestic work, and (f) women have little influence on decision making regarding farm production, marketing, and family budgets.

The survey conducted by Manatunge, Yamazawa \& Samanpriya (2019) suggests that "urgent marriages" took place among the resettlers, in that some young and single resettlers got married quickly or unexpectedly in order to be eligible for compensation as an independent household. Such a marriage is usually conducted between residents in the same village. "Dam brides" existed in both the Kotmale Dam and the Tokuyama Dam case in Japan. These women came to the project command area from distant places to marry men who were to be resettled. 


\section{Conclusion}

The five papers collected in this special issue indicate the importance of the formulation and operation of a resettlement plan to facilitate life reconstruction for resettlers. In the cases of the two dams in Indonesia, stakeholder participation does not seem to have been conducted to a sufficient degree. As a result, dam planners expected that many resettlers would participate in transmigration and leave Java. However, the majority of the resettlers chose to live near the reservoir. Moreover, the amount of the cash compensation for relocation was very small or was not given at all. Therefore, resettlers were unable to purchase sufficient farmland to re-establish their livelihoods, and their economic situation after resettlement worsened.

The largest problem with the Jatigede Dam is that its construction was suspended for more than 20 years after the resident relocation program began. Many resettlers were convinced that the dam construction project had been discontinued and did not spend the compensation money for future investments, but for daily consumption and/or investments in the land to be submerged. A large number of resettlers were displaced with sudden notification about the resettlement in 2015. The majority of the resettlers remained unemployed after the resettlement. If residents had been able to fully participate in the formulation of the resettlement plan, this situation could have been avoided.

In the cases in Indonesia, it became difficult for resettlers to continue farming after relocation. On the other hand, there were few Japanese resettlers who wished to remain farmers after resettlement. It is effective to conduct vocational training for resettlers so they can secure work other than farming. In the case of Saguling, the World Bank had a plan for the resettlers to conduct fish farming at the reservoir. However, cash compensation was not sufficient for the resettlers to purchase floating net cages. Instead, capitalists from outside conducted excessive farming on the reservoir, resulting in the deterioration of the water quality. Fish production thus decreased significantly. As a consequence, few resettlers are currently conducting fish farming (Sunardi et al., 2013). As with the Saguling Dam, the Jatigede Dam is also located in West Java Province. The provincial government has banned fish farming on the reservoir surface. However, there are people among the Jatigede resettlers who are interested in fishery. If there had been sufficient communication between the government and the residents, the residents might have been able to re-establish their livelihood by fish farming.

The provincial government planned to release fishes to the reservoir by the Jatigede Dam for the purpose of promoting tourism. It should be noted that infrastructure development to foster the local tourism industry requires huge amounts of money. In Japan, funding provided by ASMRAD was used for various infrastructure development projects to attract tourists. Such an endeavor succeeded in attracting a large number of tourists to the Shichikashuku Dam area. This lesson may be applicable in Indonesia.

Note that resettlers are not the only "players" in the game. Construction of dams also has an impact on non-resettlers living in the project command area and whose assets are not submerged. Maintaining their livelihood after completion of a dam tends to become more difficult, particularly if their area is "detached" by the reservoir from the downstream area. 
Provision of good infrastructure for traffic is essential for maintaining their connection with the downstream area, as vividly shown in the case of the Shichikashuku Dam. In Japan, ASMRAD proved to be a very useful scheme for such a situation (Nakayama \& Fujikura, 2019).

Methods for stakeholder participation in resettlement plan formulation should be considered carefully, taking local social and economic situations into account. Gender issues have seldom been addressed in the process of consensus building between project-affected people (i.e., resettlers and non-resettlers in the project command area) and dam developers. In the case of the Tokuyama Dam, women had participated in negotiations with the executing agency, but they seldom expressed their opinions due to societal pressure. It is necessary to find a way to sufficiently reflect the opinions of women. Holding meetings only with the participation of women or interviewing women individually may be possible options. Even among women, opinions and attitudes may be quite diverse, as the "dam bride" case in Tokuyama suggests. It is thus necessary to formulate a plan that takes the diverse opinions of women into consideration.

\section{Acknowledgments}

This work was supported by JSPS KAKENHI Grant Number JP16H03320. The authors very much appreciate the efforts devoted to the featured articles by our colleagues on the research team.

\section{References}

Chellaney, B. (2011). Water: Asia's new battleground. Georgetown University Press.

Cernea, M. (2003). For a new economics of resettlement: A sociological critique of the compensation principle. International Social Science Journal, 175, 37-45.

FAO. (2019). FAOSTAT: Agricultural land - area by country. FAO, Rome. Retrieved on 8 February 2019 from http://www.fao.org/faostat/en/\#data/RL/visualize.

Fujikura, R., \& Nakayama, M. (Eds.). (2015). Resettlement Policy in Large Development Projects. Routledge.

IEA. (2018a). Scenarios, World Energy Outlook. IEA, Paris. Retrieved on 8 February 2019 from

https://www.iea.org/weo/?utm_source=bottom_floater\&utm_source=bottom_floater\&tag\&su bsection\&twitterautopost\&utm_source=bottom_floater\&utm_source=bottom_floater\&tag\&s ubsection\& twitterautopost.

IEA. (2018b). World Energy Model. IEA, Paris. Retrieved on 8 February 2019 from https://www.iea.org/weo/weomodel/.

Manatunge, J., Yamazawa, S., \& Samanpriya, M. M. M. (2019). The contribution of women in rebuilding livelihoods in the long-term after involuntary resettlement: a case study of resettlers of Kotmale Dam, Sri Lanka. Journal of Asian Development, 5(1), 71-93.

Nakayama, M., \& Fujikura, R. (2019). Addressing the Livelihood of Non-Resettlers in Dam-Induced "Detached" Areas: The Case of the Shichikashuku Dam. Journal of Asian Development, 5(1), 45-55. 
Padovani, F. (2016). Development-induced displacement in India and China: A comparative look at the burdens of growth. New York: Lexington Books.

Scudder, T. (2005). The future of large dams: Dealing with social, environmental, institutional and political costs. London: Earthscan.

Sunardi, Gunawan, B., Manatunge, J., \& Pratiwi, F. D. (2013). Livelihood status of resettlers affected by the Saguling Dam project, 25 years after inundation. International Journal of Water Resources Development, 29(1), 25-34.

Sunardi, Ariyani, M., Febriani, R., Maharani, G.S., Fu, R. H. Y., \& Fujikura, R. (2019). Rebuilding livelihood of the rural and peri-urban resettlers in post-involuntary displacement of Saguling Dam construction. Journal of Asian Development, 5(1), 12-30.

Suwartapradja, O. S., Fujikura, R., Sunardi, \& Fu, R. H. Y. (2019). Resettlement caused by Jatigede Dam project: Consequence of long delayed implementation of a project. Journal of Asian Development, 5(1), 31-44.

UNFCCC. (2015). Paris Agreement. Adopted on 12 December 2015 at the twenty-first session of the Conference of the Parties to the United Nations Framework Convention on Climate Change (UNFCCC), Paris.

World Commission on Dams. (2000). Dams and development - A new framework for decision-making. London: Earthscan.

World Bank. (2012). Social Development Department, Involuntary Resettlement Portfolio Review. Retrieved on $8 \quad$ February 2019 from http://pubdocs.worldbank.org/pubdocs/publicdoc/2015/3/517941425483120301/involuntaryr esettlement-por tfolioreview-phase1.pdf.

World Bank. (2015). World Bank Acknowledges Shortcomings in Resettlement Projects, Announces Action Plan to Fix Problems. March 4, 2015. Retrieved on 8 February 2019 from http://www.worldbank.org/en/news/press-release/2015/03/04/world-bank-shortcomings-resett lement-projects-plan-fix-problems.

Yamazawa, S., \& Moriya, K. (2019). Gender issues and women's agency in involuntary resettlement: The Tokuyama Dam in Japan. Journal of Asian Development, 5(1), 56-70.

\section{Notes}

Note 1. The New Policies Scenario models based on "today's policy ambitions seem likely to take the energy sector. It incorporates not just the policies and measures that governments around the world have already put in place, but also the likely effects of announced policies, including the Nationally Determined Contributions made for the Paris Agreement." (IEA, 2018b)

Note 2. The Sustainable Development Scenario "outlines an integrated approach to achieving internationally agreed objectives on climate change, air quality, and universal access to modern energy." (IEA, 2018b) 


\section{Copyright Disclaimer}

Copyright for this article is retained by the author(s), with first publication rights granted to the journal.

This is an open-access article distributed under the terms and conditions of the Creative Commons Attribution license (http://creativecommons.org/licenses/by/3.0/). 